Олександр Буценко

старший науковий співробітник відділу мистецької науки і освіти НАМ України

\section{Oleksandr Butsenko}

senior researcher

Department of Art Research and Education

National Academy of Arts of Ukraine

amu@academia.gov.ua orcid.org/0000-0001-6236-0907

\title{
ПИТАННЯ КУЛЬТУРИ Й КУЛЬТУРНОЇ СПАДЩИНИ В ПРОЕКЦІЇ ЦІЛЕЙ СТАЛОГО РОЗВИТКУ
}

\section{Culture AND CULTURAL heRITAge ISSUES PROJECTED ON SDGS}

\begin{abstract}
Анотація. У статті розглядається розуміння ролі і місця культури та культурної спадщини в системі глобальних цілей сталого розвитку людства, визначених у резолюції Генеральної Асамблеї Організації Об’єднаних Націй від 25 вересня 2015 року «Перетворення нашого світу: Порядок денний у сфері сталого розвитку до 2030 року", на підставі сьогоднішніх підходів та поглядів, висловлених у міжнародному науково-теоретичному дискурсі, та завдань, сформульованих у політичних та стратегічних документах.

Ключові слова: глобальні цілі сталого розвитку, культура і культурна спадщина, стратегія сталого розвитку, культурне розмаїття, опори сталого розвитку.
\end{abstract}

Постановка проблеми. Глобальні цілі сталого розвитку, схвалені світовими лідерами, ставлять перед людством важливі завдання, покликані сприяти процвітанню та захисту планети. Успішне виконання цих завдань та досягнення цілей сталого розвитку вимагають координування та об’єднання зусиль, взаємодію та бачення «нашого спільного майбутнього» ${ }^{1}$. Все це має одну спільну основу - культуру.

Метою і завданням статті $є$ розглянути розуміння ролі культури і культурної спадщини для успішної реалізації стратегії сталого розвитку, зокрема, завдяки присутності в усіх визначених 17 глобальних цілях.

Викладення основного матеріалу дослідження. Початок серйозного наукового і публічного дискурсу про необхідність збалансованого і ощадливого глобального розвитку був покладений у 1970-і, коли в Стокгольмі (1972) відбулася Конференція ООН з проблем навколишнього середовища, що дала поштовх світовому природоохоронному руху. Міжнародна комісія з питань навколишнього середовища і розвитку, створена ООН у 1983 році й очолювана екс-прем’єр-міністром Норвегії Гру Гарлем Брундтланд, у своїй доповіді «Наше спільне майбутнє» вперше запроваджує концепцію сталого розвитку і ставить одне з найважливіших і найбільших завдань перед людством: сформулювати такий спосіб життя, який склав би основу довготривалого ощадливого розвитку. «Ідеться про систему цінностей, яку необхідно терміново прищепити кожній світовій культурі не як таку, що може бути безпосередньо застосована, а як складову культурного світобачення, сповнену такої ж шанобливості, як наша повага до святості життя, яка б не залежала від таких факторів, як економічні сплески чи занепади, зміна політичної влади тощо» [1, с. 10].

А проте, як пише Еврім Єльчер Єзюнель, доктор філології, доцент кафедри фольклору на Факультеті літератури Університету Хачі Байрама в Анкарі, член Національної комісії Туреччини з питань ЮНЕСКО: «У період від 1970-х років до сьогодні культуру не ставили в центр стратегій сталого розвитку, iї просувала тільки меншість, наголошуючи на важливості культури» [2]. Ідеї сталого, збалансованого розвитку, закладені в доповіді «Наше спільне майбутнє», знайшли продовження в «Порядку денному на XXI століття», ухваленому на Конференції в Ріо-де-Жанейро у 1992 році, де були визначені три основні опори сталого розвитку: економічне зростання, соціальна інтеграція та екологічна рівновага.

XXI століття підвищило розуміння ролі та місця культури в науковому та політичному дискурсі. У 2001 році австралійський науковець, один із провідних експертів у галузі культурної політики Джон Гокс випускає книгу «Четверта опора сталого розвитку. Суттєва роль культури в державному плануванні», в якій об'єднує чотири взаємопов'язані виміри: екологічну відповідальність, економічний добробут, соціальну рівність і життєвість культури [3]. Ця книга, що стала відповіддю на критичну потребу «знову ввести поняття культури в мову політиків і чиновників» [4], досі залишається одним із найцілісніших текстів у розумінні

\footnotetext{
${ }^{1}$ Назва доповіді Міжнародної Комісії ООН з питань навколишнього середовища і розвитку (1987), в основу якої була покладена «Концепція сталого розвитку».
} 
ролі та місця культури і культурної спадщини і в державній політиці, і в стратегії сталого розвитку. За Гоксом, суспільний розвиток тримається на чотирьох опорах: економічна опора має відповідати за створення матеріальних цінностей, соціальна опора розподіляє ці цінності, екологічна опора контролює при цьому відповідальність за навколишнє середовище, але коло розвитку не буде замкнене без четвертої опори - культури [5, с. 25].

Концепція моделі опор у наступних працях дослідників (M. Wehrspaun / H. Schoemps, L. Seghezzo, C. Runnalls, S. Connelly, R. Gibson, A. Hasna, N. Peterson та ін.) була розвинута переважно в трьох різновидах: як окрема четверта, а то й п’ята опора; як невід’ємна частина кожної з трьох опор; як те, що об'єднує всі опори, надає їм сенсу як цілісного механізму довготривалого і збалансованого (сталого) розвитку. Це, власне, розкриває визначення поняття «культура», про яке у згаданій вище книжці Д. Гокс пише: «Без занурювання глибоко у масив наукової літератури, створеної в різних країнах, можна виділити два взаємопов'язані визначення. A came:

- суспільне виробництво і передача ідентичності, смислів, знань, переконань, цінностей, прагнень, пам’яті, цілей, поглядів і розуміння;

- «спосіб життя» окремої групи людей: звичаї, вірування та уявлення; етикет, одяг, кухня, мова, мистецтво, наука, технології, релігія і ритуали; норми і правила поведінки, традиції та інститути» [6, с. 3].

Відштовхуючись від запропонованої Гоксом моделі, канадська дослідниця Кетрин Раннелз запропонувала в 2006 році графічне зображення взаємодії основних складових сталого розвитку, в якому три кола (три опори - соціальний вимір, екологічний вимір та економічний вимір), перетинаючись, гарантують рівність, життєздатність і відповідальність, а загальне коло, в яке вони всі вписані, що представляє культурний вимір, означає «якість життя»: цінності, прагнення, зв’язки, розмаїття, творчість, інноваційність, життєспроможність (мал. 1) [3].

Тобто сталий розвиток вимагає не просто зміни ціннісних, а й світоглядних орієнтирів, передбачаючи холістичний і творчий підхід до завдань і викликів, що постають перед сьогоднішнім суспільством. На думку Д. Пиркоша, «на зміну індустріальної парадигми має прийти холістична парадигма, що наголошує на взаємозалежності різних чинників, які визначають людське буття» [7]. Дослідник наводить порівняльну таблицю різниці між ціннісними підходами у двох парадигмах - iндустріального і сталого розвитку. Так, якщо говорити про форму аналізу і дослідження, то в моделі індустріального розвитку був присутній «атомізм» - пошук розв'язання проблем, заснований на вузько секторному аналізі з незначними посиланнями на інші елементи системи. Модель сталого розвитку передбачає, натомість, «холізм» - пошук розв’язання проблем, що спирається на всебічний аналіз взаємозалежності між елементами системи / секторами. У взаєминах людини з природою «антропоцентризм» як панівний принцип поступається місцем «біоцентризму». У соціальній системі «культурна однорідність» замінюється «культур-

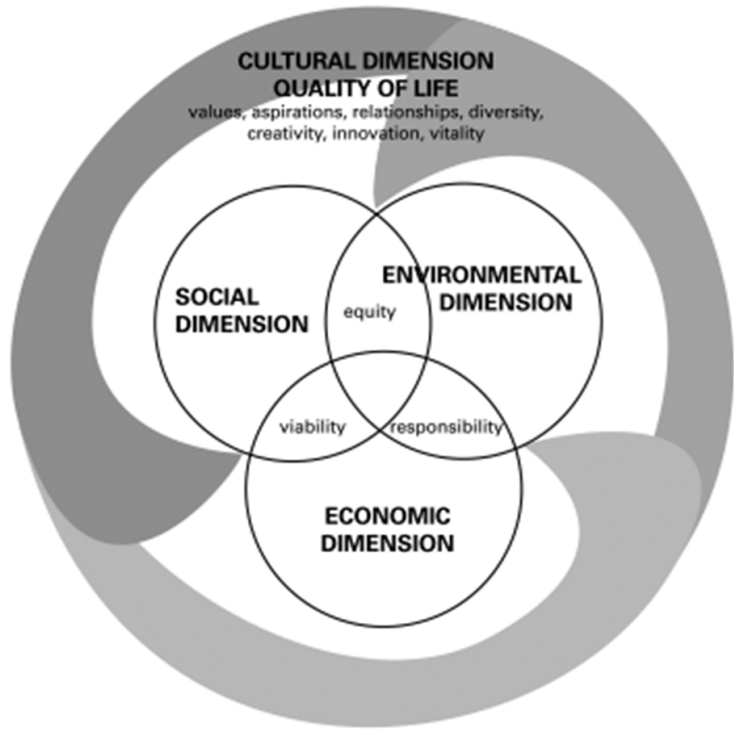

Source: Catherine Runnalls, 2006, MA thesis for Royal Rhodes University, adapted from Hawkes, 2001 and others

Мал. 1. Варіант моделі опор сталого розвитку, де культура «огортає» взамопов’язані виміри

ним розмаїттям», фокус розвитку 3 «територій міст» переноситься на «громаду та навколишнє середовище», головну форму прийняття рішень «згори вниз» замінює форма «знизу вгору». В економічній системі «змагання" поступається місцем «співпраці», а «безмежне зростання» - «зростанню в межах біосфери» [7, с. 61].

Міждисциплінарний підхід, на який спирається модель сталого розвитку, робить культуру важливим показником загального процесу. Як зазначає ще один польський дослідник Ришард Яніковський, прогрес і розвиток завжди спираються на цінності. «Що стосується сталого розвитку, то тут цінності випливають безпосередньо з базових елементів культури" [8]. Таким чином, культура «може стати потужним рушієм розвитку», а «культурна спадщина, культурні та творчі індустрії, врівноважений культурний туризм і культурна інфраструктура можуть служити стратегічними інструментами» [9] для соціально-економічного розвитку. Культура проектується у сталому розвитку в трьох вимірах [8]: культура як мета розвитку (уряди підтримують культуру, оскільки вона забезпечує доходи та робочі місця, сприяє економічному росту, посилює соціальну згуртованість та регіональний і місцевий розвиток); культура як засіб розвитку (забезпечує інструменти для зменшення бідності та покращення стандартів життя); культура як детермінанта розвитку (культура та іï елементи визначають напрямок і темп розвитку).

Питання ролі та місця культури в сталому розвитку поглибили далі у своїх працях такі дослідники, як Чарлз Лендрі, Ненсі Даксбері, Жорді Паскуаль-і-Руїс, Філ Вуд, Шарон Жаннот, Наталія Гринчева, Мілена Драгичевич-Шешич, Светлана Гристова, Емма Бломкамп та ін. Слід зазначити, що вістря їхньої уваги було спрямовано на питання сталого розвитку на регіональному та місцевому (мі- 
ському) рівнях. Як сказано в «Порядку денному на 21 століття для культури", основоположному документі Об'єднаних міст і місцевих влад (ОММВ/ UCLG), першому універсальному документі, що закладає основи зобов'язанню міст і органів місцевого самоврядування щодо культурного розвитку: «Схвалення культур і політики, яка сприяє їхньому визнанню і життєздатності, є визначальним чинником у стабільному розвитку міст і територій, а також у їхньому людському, економічному, політичному та соціальному плані. Головною рисою державної культурної політики є вимога громад у сучасному світі» [10].

Можна зазначити, що протягом перших 15 років XXI століття активний науковий дискурс, що розгорнувся від Австралії до Канади та Великої Британії, від Іспанії до Фінляндії, вплинув на загальне сприйняття й розуміння ролі та місця культури в соціально-економічному розвитку на всіх рівнях, у державній та місцевій політиці, в загальній стратегії розвитку людства. На січень 2012 року культуру було включено у 70 \% Рамкових програм ООН з надання допомоги [11], зокрема й програм розвитку (ООН-ХАБІТАТ), що здійснювались в Україні («Стратегічний менеджмент у місцевому самоврядуванні»). Загальному процесу сприяли й зусилля багатьох міжнародних організацій, зокрема вже згаданої вище Всесвітньої асоціації Об'єднаних міст і місцевих влад, яка в травні 2014 року розпочала кампанію «Майбутнє, якого ми бажаємо, включає культуру», збираючи підписи під Декларацією «Про включення культури до глобальних цілей сталого розвитку». До кінця вересня 2015 року, часу проведення 70-ї Генеральної Асамблеї ООН, яка схвалила Резолюцію «Перетворення нашого світу: Порядок денний у сфері сталого розвитку до 2030 року», під Декларацією поставили підписи 900 організацій та понад 2500 осіб зі 120 країн світу.

Та хоч такий об’єднаний голос на підтримку культури й позначився на прийнятті політичних рішень i, мабуть, уперше в історії чітко прозвучав у стратегічному документі щодо глобального розвитку, та сама стара проблема зверхнього ставлення і розуміння ролі культури в площині політичного дискурсу залишається й досі відкритою. «Політична проблема полягає в тому, що культура в широкому розумінні вимагає крос-секторної чи навіть міждисциплінарної політики, а також інноваційних, часом аж радикально відмінних способів ії реалізації, що передбачає перегляд широкого спектра питань, як от: управління, демократична участь і соціальна рівність» [12, с. 14].

Згадана вище Резолюція ООН визначила 17 цілей сталого розвитку людства до 2030 року як амбіційний «план дій для людей, планети та процвітання» [13]. I хоч жодна з 17 цілей безпосередньо не стосується культури, загальний Порядок денний містить окремі завдання, що мають пряме посилання на культуру. Так, уперше слово "культура» згадується в завданні 4 цілі 7 «Забезпечення всеохоплюючої і справедливої якісної освіти та заохочення можливості навчання впродовж усього життя для всіх». Це завдання звучить так: «До 2030 року забезпечити, щоб усі учні здобували знання і навички, необхідні для сприяння сталому розвитку, у т. ч. шляхом навчання з питань сталого розвитку та сталого способу життя, прав людини, гендерної рівності, сприяння культурі миру та ненасильства, громадянства світу й усвідомлення цінності культурного різноманіття і вкладу культури в сталий розвиток» [13]. Вдруге "культура» безпосередньо згадується у цілі 8, визначеній у Резолюції ООН, - «Сприяння безперервному, всеохопному і сталому економічному зростанню, повній і продуктивній зайнятості та гідній праці для всіх». Завдання 3 ставить за мету «Просувати проведення орієнтованої на розвиток політики, яка сприяє продуктивній діяльності, створенню гідних робочих місць, підприємництву, творчості й інноваційній діяльності...", а завдання 9 пов’язує місцевий розвиток з культурою і туризмом: «До 2030 року розробити та реалізувати політику сприяння розвитку сталого туризму, який забезпечує створення робочих місць і сприяє розвиткові місцевої культури та виробництву місцевої продукції». Це завдання доповнюється в цілі 12 (b): «Розробляти та впроваджувати інструменти моніторингу впливу сталого розвитку на розвиток сталого туризму, який сприяє створенню робочих місць, а також розвитку місцевої культури та виробництву місцевої продукції». Нарешті, в цілі 11 про «Забезпечення відкритості, безпеки, життєстійкості й екологічної стійкості міст і населених пунктів» $є$ завдання 4, де уряди країн закликають «Активізувати зусилля із захисту і збереження світової культурної та природної спадщини».

Водночас, беручи до уваги думку, висловлену в Резолюції Генеральної Асамблеї ООН (Декларація, п. 36) про те, що світові уряди зобов'язуються «сприяти міжкультурному розумінню, терпимості, взаємній повазі та етиці глобального громадянства і спільної відповідальності. Ми усвідомлюємо природну і культурну різноманітність світу й визнаємо, що всі культури та цивілізації можуть сприяти сталому розвитку і виступають вирішальними чинниками його забезпечення» [13], можна сказати, що успішне досягнення цілей «безпрецедентного за масштабами та значущістю» [13] прийнятого усіма країнами Порядку денного буде можливим лише тоді, коли культура відіграє центральну роль і в тих сферах, де зв'язок із нею видається непрямим, адже «культурні права, культурна спадщина, культурне розмаїття і творчість є головними компонентами людського і сталого розвитку» [14].

Кращому розумінню ролі культури та культурної спадщини в процесі сталого розвитку покликані служити політичні документи, розроблені останніми роками ЮНЕСКО. Назвемо два, на нашу думку, найголовніші з них у цьому плані. Насамперед, це нова редакція (2018) Оперативного керівнищтва з реалізацї Конвениї ЮНЕСКО про охорону нематеріальної культурної спадщини, де введено спеціальний розділ VI «Охорона нематеріальної культурної спадщини та сталий розвиток на національному рівні». Статті 170-197 охоплюють практично всі 17 глобальних цілей сталого розвитку, відштовхуючись від завдань вказаної Конвенції щодо охорони нематеріальної культурної спадщини та завдань, які стоять перед кожною державою, що ратифікувала Конвенцію (а їх на сьогодні 178), «держави-члени Конвенції мають використати всі можливі засоби, щоб визнати важли- 
вість і посилити роль нематеріальної культурної спадщини як рушія та гаранта сталого розвитку, а також повністю інтегрувати охорону нематеріальної культурної спадщини в свої плани, політику та програми розвитку на всіх рівнях» [15].

По-друге, це «Культура: індикатори 2030. Тематичні показники щодо культури в Порядку денному до 2013 року», оприлюднені ЮНЕСКО в 2019 році, де відстежується взаємозв'язок з усіма конвенціями ЮНЕСКО, починаючи від Конвенції про захист культурних цінностей у разі збройного конфлікту (1954) і закінчуючи Конвенцією про охорону та заохочення розмаїття форм культурного самовираження (2005). У документі запропоновано чотири тематичні виміри: екологія і життєстійкість; економічне зростання і продуктивність; знання і навички; всеохопність та участь.

Можна підсумувати, що широкий і потужний науковий дискурс про роль і місце культури та культурної спадщини в сталому розвитку, який розгорнувся у багатьох країнах світу протягом останнього десятиліття, а також активна позиція та діяльність міжнародних асоціацій, державних і громадських організацій справили вплив на політичні рішення і поступово вилилися у важливі положення міжнародних декларацій, резолюцій та стратегічних документів, хоч і досі, як справедливо відзначають дослідники та експерти, культура не стоїть у центрі стратегій розвитку.

Запропоновані в Україні проекти стратегічних документів, що стосуються сталого розвитку, зокрема, проект Закону України «Про Стратегію сталого розвитку України до 2030 року», який відкликано для доопрацювання, розвивають міжнародну тенденцію прямого і опосередкованого врахування культурних аспектів, спираючись на місцеві особливості та можливості [16]: Операційна иіль 2.3. 3абезпечити сталий розвиток регіонів на основі збереження національних культурних иінностей і традицій - «Сприяти подальшому розвитку регіонів на основі врахування збалансованості природних, природно-ресурсних, історичних, соціокультурних чинників розвитку кожного регіону.

Забезпечити захист та збереження наявних об’єктів всесвітньої культурної і природної спадщини та активізувати діяльність щодо розширення переліку таких об’єктів на території України.

Сприяти розвитку української культури та підтримці культур народів України».

Слід зазначити, що в Україні пряме чи опосередковане введення культурного аспекту в стратегічні чи програмні документи розвитку випливає переважно з попереднього практичного та політичного досвіду - реалізації міжнародних проектів розвитку, що спиралися на культуру чи культурну спадщину, на місцевому, регіональному чи національному рівнях, а не з аргументів вітчизняних теоретичних та наукових досліджень. Голос останніх, на жаль, поки слабкий, а політичні діячі та державні стратеги у своїй діяльності, зазвичай, схильні посилатися на аргументи ззовні та імплантувати чужий досвід, що часто-густо призводить до нульових, а то й негативних результатів.

Саме тому посилення науково-дослідної діяльності, на нашу думку, є одним із найважливіших векторів для підвищення ролі культури в стратегіях сталого розвитку України та успішної реалізації цих стратегій. На це чітко вказано в Указі Президента України (№722/2019) «Про цілі сталого розвитку України на період до 2030 року»: «Рекомендувати Національній академії наук України, Національній академії аграрних наук України, Національній академії медичних наук України, Національній академії педагогічних наук України, Національній академії правових наук України, Національній академії мистецтв України враховувати Цілі сталого розвитку України на період до 2030 року під час визначення напрямів наукових досліджень» [17].

Висновки. Розуміння місця і ролі культури та культурної спадщини в стратегіях сталого розвитку на міжнародному, національному чи місцевому рівнях відчутно зросла протягом останнього десятиліття. Цьому посприяли широкі та грунтовні дослідження питання, здійснені науковцями різних країн, а також активність міжнародних асоціацій та організацій, таких як Всесвітня асоціація Об’єднаних міст і місцевих влад, ЮНЕСКО, численних громадських та наукових організацій. У базових міжнародних стратегічних документах сталого розвитку питання культури та культурної спадщини або безпосередньо вказані у поставлених завданнях, або опосередковано пов'язані з ними. Разом $з$ тим, як відзначають багато дослідників, ці питання, на жаль, не зайняли центрального, належного їм місця.

В Україні також помітна тенденція поступового розуміння ролі та значення культури і культурної спадщини в стратегії сталого розвитку на всіх рівнях. Проте таке розуміння і включення культурних аспектів у стратегічні документи випливає, швидше, з успішних практик реалізації міжнародних проектів розвитку, базованих на культурі чи культурній спадщині (таких як «Створення культурного капіталу» (ССС), «Модель 21», «Київська ініціатива», «Хабітат-ООН», «Інтеркультурні міста», «Мапування культурних ресурсів міст», COMUS та ін.), ніж з аргументів вітчизняних наукових і теоретичних досліджень. Саме тому посилення науково-дослідної діяльності є одним із найважливіших векторів для підвищення ролі культури в стратегіях сталого розвитку України та успішної реалізації цих стратегій. На що чітко вказано в Указі Президента України «Про цілі сталого розвитку України на період до 2030 року».

\section{Література}

1. ЕкоЛогіка! Природоохоронна освіта. Фонд «За чистоту Швеції». Український переклад — Данагордс графіска. Стокгольм, 2010.

2. Evrim Ölçer Özünel. «An action plan for people, planet and prosperity»: the critical approach to the 2030 sustainable development goals and safeguarding of the intangible cultural heritage. Milli Folklor, 2017, № 29, page 18-32. URL: http://www.millifolklor.com/PdfViewer.aspx?Sayi=116\&Sayfa=18 
3. Models of Sustainability Incorporating Culture // Creative Cities News. Special Edition 4 - Creative City Network of Canada. Vancouver, 2007.

URL:https://www.creativecity.ca/database/files/library/Creative_City_News_E.pdf

4. Yencken D. Foreword // In John Jawkes. The Fourth Pillar of Sustainability: Culture' s essential role in public planning. Cultural Development Network, Victoria, Australia. 2001. P. iii

5. Паскуаль-і-Руїс Ж., Драгоєвич С., Дітахмаєр Ф. Довідник з питань участі громадян у формуванні культурної політики європейських міст. К., Центр розвитку «Демократія через культуру», 2007. 6. Jawkes J. The Fourth Pillar of Sustainability: Culture' s essential role in public planning. Cultural Development Network, Victoria, Australia. 2001.

7. Damian S. Pyrkosz. Integrating Culture into (Sustainable) Development - Values, Implications and Dilemmas // Nierowności Społeczne a Wzrost Gospodarczy. nr 38 (2/2014). University of Rzeszow, Rzeszow, Poland, 2014. URL:

https://www.researchgate.net/publication/293794083_Integrating_Culture_into_Sustainable_Development_-_Values_Implications_and_Dilemmas

8. Janikowski R., 2009, Kultura osią zrównoważonego rozwoju // Kultura a zrównowa-żony rozwój. Środowisko, ład przestrzenny, dziedzictwo, R. Janikowski, K. Krzysztofek (eds.), Polski Komitet do spraw UNESCO, Warszawa.

9. UNESCO, 2012, Culture: a driver and an enabler for sustainable development, UN System Task Team on the Post-2015 UN Development Agenda, New York.

10. Завдання на 21 століття для культури. I. Принципи. 10 - United Cities and Local Governments. Ajuntament de Barcelona, Institut de Cultura - ЦР «Демократія через культуру», переклад українською, 2004. URL:

http://www.agenda21culture.net/sites/default/files/files/documents/multi/ag21c_uk.pdf

11. Culture: a driver and an enabler of sustainable development - UNESCO, May 2012. URL: https://www.un.org/millenniumgoals/pdf/Think\%20Pieces/2_culture.pdf

12. Culture in, for and as Sustainable Development. Conclusions from the COST Action IS1007 Investigating Cultural Sustainability. Ed. by Joost Dessein, Katriina Soini, Graham Fairclough and Lummina Horlings. University of Jyväskylä, Finland, 2015.

13. Перетворення нашого світу: Порядок денний у сфері сталого розвитку до 2030 року. Резолюція, прийнята Генеральною Асамблеєю 25 вересня 2015 року. URL: http://sdg.org.ua/ua/resources-2/3442030-2015

14. Culture in the Sustainable Development Goals: A Guide for Local Action - United Cities and Local Governments, 2018.

URL: https://www.uclg.org/sites/default/files/culture_in_the_sdgs.pdf

15. Operational Directives for the Implementation of the Convention for the Safeguarding of the Intangible Cultural Heritage - UNESCO Headquarters, Paris, 2018. URL: https://ich.unesco.org/doc/src/ICH-Operational_Directives-7.GA-PDF-EN.pdf

16. Проект Закону про Стратегію сталого розвитку України до 2030 року. № 9015 від 07.08.2018. Верховна Рада України. Офіційний веб-портал. URL: http://w1.c1.rada.gov.ua/pls/zweb2/webproc4_2?pf3516=9015\&skl=9

17. Указ Президента України №722/2019 від 30 вересня 2019 року. Пункт 3. Офіційне інтернет-представництво Президента України. URL: https://www.president.gov.ua/documents/7222019-29825

\section{References}

1. EkoLogika! Pry`rodooxoronna osvita. Fond «Za chy`stotu Shveciyi». Ukrayins`ky`j pereklad — Danagords grafiska. Stokgol `m, 2010.

2. Evrim Ölçer Özünel. "An action plan for people, planet and prosperity»: the critical approach to the 2030 sustainable development goals and safeguarding of the intangible cultural heritage. Milli Folklor, 2017, \# 29, page 18-32. URL: http://www.millifolklor.com/PdfViewer.aspx?Sayi=116\&Sayfa=18

3. Models of Sustainability Incorporating Culture // Creative Cities News. Special Edition 4 - Creative City Network of Canada. Vancouver, 2007.

URL:https://www.creativecity.ca/database/files/library/Creative_City_News_E.pdf

4. Yencken D. Foreword // In John Jawkes. The Fourth Pillar of Sustainability: Culture' s essential role in public planning. Cultural Development Network, Victoria, Australia. 2001. P. iii

5. Paskual `-i-Ruyis Zh., Dragoyevy`ch S., Ditaxmayer F. Dovidny`k z py`tan `uchasti gromadyan u formuvanni kul `turnoyi polity`ky`yevropejs `ky`x mist. K., Centr rozvy `tku «Demokratiya cherez kul `turu», 2007. 6. Jawkes J. The Fourth Pillar of Sustainability: Culture' s essential role in public planning. Cultural Development Network, Victoria, Australia. 2001.

7. Damian S. Pyrkosz. Integrating Culture into (Sustainable) Development - Values, Implications and Dilemmas // Nierowności Społeczne a Wzrost Gospodarczy. nr 38 (2/2014). University of Rzeszow, Rzeszow, Poland, 2014. URL:

https://www.researchgate.net/publication/293794083_Integrating_Culture_into_Sustainable_Development___Values_Implications_and_Dilemmas

8. Janikowski R., 2009, Kultura osią zrównoważonego rozwoju // Kultura a zrównowa-żony rozwój. Środowisko, ład przestrzenny, dziedzictwo, R. Janikowski, K. Krzysztofek (eds.), Polski Komitet do spraw UNESCO, Warszawa. 
9. UNESCO, 2012, Culture: a driver and an enabler for sustainable development, UN System Task Team on the Post-2015 UN Development Agenda, New York.

10. Zavdannya na 21 stolittya dlya kul `ury`. I. Pry`ncy`py`. 10 - United Cities and Local Governments. Ajuntament de Barcelona, Institut de Cultura - CzR «Demokratiya cherez kul `turu», pereklad ukrayins`koyu, 2004. URL:

http://www.agenda21culture.net/sites/default/files/files/documents/multi/ag21c_uk.pdf

11. Culture: a driver and an enabler of sustainable development - UNESCO, May 2012. URL: https://www.un.org/millenniumgoals/pdf/Think\%20Pieces/2_culture.pdf

12. Culture in, for and as Sustainable Development. Conclusions from the COST Action IS1007 Investigating Cultural Sustainability. Ed. by Joost Dessein, Katriina Soini, Graham Fairclough and Lummina Horlings. University of Jyväskylä, Finland, 2015.

13. Peretvorennya nashogo svitu: Poryadok denny `j u sferi stalogo rozvy `tku do 2030 roku. Rezolyuciya, pry jnyata General `noyu Asambleyeyu 25 veresnya 2015 roku. URL: http://sdg.org.ua/ua/resources-2/3442030-2015

14. Culture in the Sustainable Development Goals: A Guide for Local Action - United Cities and Local Governments, 2018.

URL: https://www.uclg.org/sites/default/files/culture_in_the_sdgs.pdf

15. Operational Directives for the Implementation of the Convention for the Safeguarding of the Intangible Cultural Heritage - UNESCO Headquarters, Paris, 2018. URL: https://ich.unesco.org/doc/src/ICH-Operational_Directives-7.GA-PDF-EN.pdf

16. Proekt Zakonu pro Strategiyu stalogo rozvy`tku Ukrayiny` do 2030 roku. \# 9015 vid 07.08.2018. Verxovna Rada Ukrayiny`. Oficijny`j veb-portal. URL: http://w1.c1.rada.gov.ua/pls/zweb2/webproc4_2?pf3516=9015\&skl=9

17. Ukaz Prezy`denta Ukrayiny`\#722/2019 vid 30 veresnya 2019 roku. Punkt 3. Oficijne internet-predstavny`cztvo Prezy`denta Ukrayiny`. URL: https://www.president.gov.ua/documents/7222019-29825

\section{Butsenko 0.}

\section{Culture and cultural heritage issues projected on SDGs}

The article analyzes the understanding of role and place of culture and cultural heritage in the set of global sustainable development goals of mankind determined in the Resolution of UN General Assembly as of 25 September 2015 Transforming our world: the 2030 Agenda for Sustainable Development, basing on actual approaches and views expressed in the international scientific and theoretical discourse, and tasks formulated in political and strategic documents.

Keywords: global sustainable development goals, culture and cultural heritage, sustainable development strategy, cultural diversity, pillars of sustainable development.

\section{Буценко А.}

\section{Вопросы культуры и культурного наследия в проекции целей стабильного развития}

Рассматривается понимание роли и места культуры и культурного наследия в системе глобальных целей стабильного развития человечества, определенных в резолюции Генеральной Ассамблеи ООН от 25 сентября 2015 года «Преобразование нашего мира: Повестка дня в сфере стабильного развития до 2030 года», на основе сегодняшних подходов и взглядов, высказанных в международном научно-теоретическом дискурсе, и заданий, сформулированных в политических и стратегических документах.

Ключевые слова: глобальные цели стабильного развития, культура и культурное наследие, стратегия стабильного развития, культурное разнообразие, опоры стабильного развития. 